\title{
Being and Slime: An Alluvial Introduction
}

\section{Karin Sellberg \& Kamillea Aghtan}

'Dirty', 'messy', 'grubby', 'perverse' and 'disorderly' are the adjectives usually used in relation to secretion of body fluids. Even when spoken of in appreciatory terms, fluidity tends to be 'otherised'; it is appreciated because it is messy, abject, strange or queer. The disturbing uncontainability of our body fluids force them either into the realm of the disgusting or the erotically tantalising. They are the perpetual opposites of our firm and graspable corporeality, its peculiar and erratic shadow.

When it comes down to it, there are few things less strange than fluidity, however - and this special issue is not another attempt to perpetuate the titillating discourses of 'grubbiness' surrounding it. By focusing on specific fluids in isolation, as well as in patterns of discursive and material fluid exchange - and by problematising the very idea of fluidity in the first place - we hope to come one step closer to the as yet unfathomable 'core' of this elusive matter. We secrete sweat, saliva, urine, blood, seminal and fecal fluids (and so on) on a daily basis, and our entire physical apparatus is perpetuated (although never twice in materially identical forms) through continual internal and external exchanges of fluids.

Of course, the very fact that the substances we're discussing are fluids, makes any sense of a 'core', or indeed a comprehensible corpus, practically impossible. We are not planning to substantiate or stabilise a concept that in its very definition must remain loose and fleeting. Classic academic rhetorics do not allow for unsubstantial logic - there is no rational gravity in an argument that always already abandons your grasp. The lack of a 'solid' line of thought does not necessarily imply a lack of material presence, however. Just as a body of water remains a 'body' despite its consistent flow, fluid thoughts may take on forms without firmament. This introduction will follow such a reflective stream of consciousness - a light and fluid logic, travelling from one strand of thought to another, moving in currents. Characterised as an 'alluvial' logic - our text is a trace, or embodiment, emerging through movement itself. It is the rhizomatic shape appearing in the wake of our thoughts. 
As Michel Foucault continually reminds us, texts are embodied and being is determined by the textuality of materiality. ${ }^{1}$ This being said, the written word will never truly 'capture' or recreate the essence of being. Gilles Deleuze and Felix Guattari argue in their introduction to $A$ Thousand Plateaus that "a book exists only through the outside and on the outside" - and this is its great strength as well as its failure (p.4). The necessary gap between being and textuality gives it a transformative ability. In view of such enabling separation, or abstraction, this text attempts to be an embodying (rather than an embodied) 'root' machine: the image of alluvium is an abstract apparatus that simultaneously aims to bring together and pull apart the "multiple, lateral, and circular system[s] of ramification" with which our physicality presents us. The suggestive title of our conceptual journey, 'being and slime', combines two aspects of Western corporeality that are deeply at odds with each other - classic Heideggarian ontology and the often 'messy' reality of the body - and our alluvial apparatus deconstructs this seemingly dichotomous relationship.

\section{Part I: Fluidity}

As the performance artist Bob Flanagan argues, contemporary ideas of embodiment are generally made 'presentable' in academic as well as in cultural discourse - they are thoroughly 'neatened' or 'dried' up. In his documentary Sick: The Life and Death of Bob Flanagan, Supermasochist, Flanagan discusses the American educational model company Skillcraft's construction of a 'Visible Man', stated on the carton to be an "anatomically accurate scaled-down version of man". It is an attempt to create a veritable and realistic micro-man, with transparent skin and subcutaneous fat layers and complete intestinal and circulatory systems, available to any child or curious adult to perceive and peruse. The body's various layers can be built up, peeled off and interspersed, and the organs connected and disconnected at the user's whim.

Bob Flanagan is not content with this micro-model of humanity, primarily because of its comprehensibility and completeness - each part of the micro-body is solid, and there is no communication or movement within or without the system. Whereas the 'Visible Man' is an intact body, Flanagan contends that his body is not, and never will exhibit such stability. His performance art, interviews and documentaries focus on his life as a 'super-masochist' and life-time sufferer of cystic fibrosis. As such, his experience of embodiment is a continuous negotiation with fluidity - his is a punctured, porous and dramatically leaky body. 
Flanagan thus decides to construct a new "autobiographical version" of the 'Visible Man' for his exhibition, 'Visiting Hours' (Santa Monica Museum of Art, 1992), creating the basis for a new, explicitly runny and mucous ontology (Sick). Flanagan's medical condition forces him to constantly cough up green phlegm, which he arranges, using a small pump, to issue forth from the personalized doll's mouth. Since cystic fibrosis also gives him chronic diarrhoea, exacerbated by his medication, a mixture of Alberto VO5 hair conditioner and tempeh pate continually dollops from the model's miniature sphincter muscle. Finally, Flanagan's sexual masochism gives him ample opportunity to enjoy his condition, so he furnishes his visible man with a continuous ejaculatory dribble, "straight from a bottle" of White Rain hair conditioner (Sick).

Flanagan's leaky body stands out from the general idea of the intact body because of the extremity of his effusions, yet none of these bodily emissions are particular to his condition or sexual proclivities. As Margrit Shildrick shows in Leaky Bodies and Boundaries, corporeality sustains itself through continual exchange of fluids, and any conception of corporeality that does not take this into account misses out on its most pivotal material function - sustenance of the life processes. Life, as Henri Bergson defines it (Creative Evolution, p. 5), possesses a motive and fundamentally fluid quality - and, in fact, science tells us that 90 per cent of the female body and 70 per cent of the male body consists of water (Martini and Nath, p. 568). The vitality of the living flesh is dependent on the body's infusive and effusive mechanism - it only stabilises the moment it dies and then another process of exchange begins as the body starts to decompose.

Flanagan's body, like any living body, can thus be seen as an amalgamation of the more or less solid flesh and bone that compound him and the transportative fluids that simultaneously sustain and escape him. There is solid flesh and intermediary fluids. Yet, Flanagan's visible man does not account for the more ambiguous substances of the body. Corporeal being is not merely a binary systematisation of stable matter and liquid dialysis. The human body contains many ambiguously soggy segments and liquidising layers that neither should be categorised as moisture or matter. As Deleuze and Guattari (in many ways taking their cues from Bergson) and numerous of their feminist and queer readers including Rosi Braidotti and Margrit Shildrick argue, corporeality is a composite and continually metamorphic construct, which so far has not been possible to capture or represent in Western philosophy. 
The contemporary idea of 'being', in many ways harking back to Martin Heidegger's ontology and the seminal Sein und Zeit (Being and Time), tends to operate as an entirely abstract and disembodied reflection of corporeality. There is a type of corporeality in Heidegger; however, the body in question is very solid, three-dimensional and intact. Although Heidegger argues that the sense of being is constructed in relation to a sense of being-in-the-world, this corporeal "in" is only significant as far as it enables the Dasein. The body is presented as the carrier of the senses and the locus of phenomenological experience - the place where being happens. Being exist only by the fact that "there is an entity which has made a disclosure of spatiality as the Being of the 'there'" (Heidegger, 2008, p. 171, emphasis added), but this entity is a mere vessel for the Dasein.

Indeed, for Heidegger, the Being question necessitates a departure from the body as such: "The existential analytic of Dasein comes before any psychology or anthropology, and certainly before any biology" (Heidegger, 1993, p.106). His often-discussed refusal to consider the body within Being and Time also neatly displaces the subject, performance and substance from his grander exploration of a holistic ontology. Thus a curious absence permeates his conception of Dasein. This is an absence of not merely bodies-in-the-world but, just as imperatively, of bodies complexly entangled-with-the-world: the hammerer (holding Heidegger's philosophical hammer) but also the thumb made unwieldy and strange to itself by the errant hammer stroke; the embodied being but also the constant leaky failure to actually em-body such a cohesive state of Being-in.

This failure is not unique to Heidegger. In an interview with Phillip Ottermann, celebrity-novelist Charlotte Roche argues that German culture has thus been stripped of all expressions for the inconveniently wet, soggy and messy reality that physicality presents to us. We are (culturally and ontologically) charged with evacuating the offensive fluidity from any relation to our experience of Being-in as its presence exists in relation of anxiety to our selves. Such a process of casting away this corporeal seepage, thus rendering it not an element of our existence, requires a kind of ontocorporeal evasion. We must "turn away" (to appropriate Heideggerian terminology) from the possible connectedness of this slimy excess of corporeality to not merely the body but also to Being in its relationality to its bodily vessel. Exposed to the threat of our own incompleteness, we plummet into anxiety, asserts Heidegger (1993, p. 71). By "turning away" from this loss, we literally suture being into an autonomous totality, knowing, for however fleeting a time, the completely 
individualised structure of Dasein - at least, until we once more drown in the sensations of our being "there" in the world (1993, p. 99).

In turning away from this vision of pulpy corporeality, there is a certain cold comfort that lies in the reassurance of our selves laying claim to whole bodies and thus securing our own beings as individual, autonomous and whole. Buffeted by the possible lack of bodily sovereignty (that is, by a loss of mastery over one's own body), yet aware of the completeness of material existence through this very possibility of incompleteness and unknowability, it is this liminality which Julia Kristeva identifies as "simultaneously beseeching and pulverising [its] subject" (1982, p.5). And within the depths of our discomfort lies the anxiety that something of an ineffable existence might also be able to seep out of itself, becoming unlimited and foreign.

In the leaky, fluidified and ever-disintegrating corpus, we believe we find a body impossibly but tantalisingly abject with itself, a Kristevan corporeality thoroughly at odds with Heidegger's bodily absence and in complete conflict with his displacement of "biological", component and corporeal parts within the holistic ontology of Dasein. However, one thinker can be bridged with the other, from Dasein to abjection, even at the basest level of the nomenclature which they utilise: of Heidegger's motion of "thrownness" (Geworfenheit), and of the "abject", from the Latinate $a b$ ("before") and iacere ("to throw").

Heidegger posits that in turning away from the vision of the unnameable, unrecognisable secretions from the body which threatens to cast us into the void of incompleteness, we transcend our immanence to the world; we are "thrown" into being by glimpsing the form of and becoming subject to our being, and by thus recognising our being-in-the-world (Heidegger, 2003, pp. 174-5). For Kristeva, the decaying leakiness of the body is denied (as Roche suggests) through abjection:

A wound with blood and pus, or the sickly, acrid smell of sweat, of decay ... are what life withstands, hardly and with difficulty, on the part of death. There, I am at the border of my condition as a living being. My body extricates itself, as being alive, from that border. (p. 3) 
If - unlike the fluid and suppurating body, or the wet and leaky being of Roche's central character, or even the living and simultaneously disintegrating corpus of queer theory - Heidegger's being turns away from the sickening incompleteness of being's body and its attendant bodily discharges, so too does Kristeva's process of identifying the abject corporealise the other in order to cast it away from being.

Leaking out from that absence which riddles Heidegger's bodiless and conceptual 'being', we find implicit fleshy relations that must refuse the possibility of their own disintegration in order to exist. Indeed, both Heidegger and Kristeva's employed physicality corroborate to preserve the completeness of being. We throw ourselves upwards - turned away from the gorge before us which is filled with messy and amorphous, un-unitised fluidity - into primordial knowledge of existence and, indeed, a transcendent knowledge (Heidegger, 1993, p. 106; see also Cerbone, 2000, pp. 209-230). For the Latinate $a b$ before the "throwing" of the $a b$-ject indicates both a direction for Heidegger's thrownness: if we cannot throw the incomplete, the fluid (and under the terms of the abject, the sickly and deathly) below us by "turning away" and thus preserving our ontologically complete being, then we must cast ourselves above it. In other words, we head towards a form of transcendence (whether we obtain it or not) which function through knowing, alienation and denial.

In Kristeva's renegotiation of Heidegger,

Dasein understands itself in relation to that which is foreign to it. ... For Heidegger, the examination of being throws Dasein outside of itself, towards structures that are both escaping and defining it. Such a transcendental institution of the other ... push[es] me towards an alterity that will force me to question, interrogate and think (Sjöholm, 2005, p. 112)

Both thinkers accordingly suggest that the transcendent form of wholeness operates only through a dialectic in which the proximity of the abject persistently threatens and confirms the resulting unity. For Kristeva, the precarity of such an encounter simultaneously compels examination and problematisation of 'unity', while also refusing the process of our own corporeal refluidification. It is a continual process of reconsolidation. 
Roche's novel Wetlands attempts to break the vicious circle of abjection. This is not conducted in the Kristevan manner of continuous reiteration of difference, but rather "throws" (to persist with Heidegger's terminology) the body ruthlessly and inescapably into the mire of the $a b$ (that is, into the "below") and by so doing explodes the very dialectic of this vertical mobility. Roche remarks to Ottermann that her book is an attempt to reclaim the 'moist' parts of the body and thus to reconstitute the true corporeal. Her heroine, the eighteen-year-old Helen Memel, revels in the 'juicy' and 'smegmatic' experiences that her body proffers her. Helen progressively perceives herself in relation to her slimy membranes and bodily emissions - she opens herself up to and embraces a moistened idea of her own Being-in. Refluidification, the body without the crossing of transcendence, refuses Heidegger's thrownness above and across the gorge of non-knowing and Kristeva's abject-normal binary.

The novel conducts a persistent and often disturbing refluidification of corporeality, however, there are a few passages that particularly demonstrate Helen's ability to actively relubricate her sense of being. Admitted to hospital because of an intimate shaving accident, which has caused her haemorrhoids to become seriously infected, the protagonist pleads with the doctor to let her keep her own surgical waste so that she can 'hold it in [her] hand and examine it' (p.8). When she finally receives it, fighting a powerful sense of abjection, she removes the slimy pieces of flesh from the zipper bag - and her immediate response is to eat it:

My fingers are covered with blood and goop. Wipe them on the bed? That would make a real mess. Not on my tree-top-angel outfit, either. Same mess. $\mathrm{Hmm}$. Well. It is all stuff from my own body. Even if it is infected. I lick my fingers off one at a time. [...] Why should i be disgusted with my own blood and pus? (p. 77)

Such a reaction might be a powerful reversal of the abject into something transcendental. Helen experiences a sense of elation when she sucks the abject matter out of her body; it is obvious that eating her infected bits of flesh excites her. The argument she presents to herself is that there is no reason why she should find these substances abject, since they are a part of herself. Helen tells the doctor: 'I don't like the idea that a part of me could end up in the trash along with aborted foetuses without my being able to picture it' (p. 8). 
The knowledge of the self is the reason why she also needs to touch, taste and smell her own vaginal 'smegma' before any form of sexual encounter. She reports that she never allows another person near her without an initial sampling of the product she has to offer:

I hike up my skirt and wriggle my hand into my underwear. I stick my middle finger deep into my pussy and leave it in the warmth for a moment before taking it back out. I open my mouth and stick my finger all the way in. I close my lips around my finger and pull it out slowly. I lick and suck as hard as I can in order to get as much of the taste of the slime on my tongue as possible. (p. 46)

This is a necessary preparatory measure for Helen, since 'There is no way I can spread my legs for some guy - to get thoroughly eaten out for instance - without knowing myself how everything looks, smells, and tastes down there' (p.46).

Roche tells Ottermann that German ontology has been effectively cleaned up and dried out. It has been erased from all phenomenological accounts of selfhood. Wetland's protagonist goes out of her way to create a multi-sensorial experience of her physical 'waste' and discharge. Her body comes to represent German corporeality and she is a corporeal explorer. As such, she needs to fully map the new territories she discovers in the unchartered wetlands of the German Dasein.

We tend to conceptualise bodies and bodily substances as solids: shit is packed into turds, ejaculatory fluids belong to the genitals that emit them and blood and pus are considered in terms of the residual scars and scabs that are formed through their release. Canonical queer theorists such as Tim Dean, Judith Butler, Jack Halberstam and even Elizabeth Grosz generally emphasise the fluidity of identity, or our sense of being, but the physical body persists as a solid entity. The flesh itself is seldom discussed - and even when it is, it is hardly ever examined in terms of its liquidising autonomy.

Eve Kosofsky Sedgwick's work is an exception. Several of her books, poems and articles, most notably her contemplations surrounding cancer and fat in Tendencies, Dialogues of Love and Fat Art, Thin Art, consider the ways in which her body affects her. Because of her long fight against 
breast cancer, Sedgwick's flesh unequivocally determines Sedgwick's Dasein and the treacherous cells thus entirely come to reconstitutes her sense of self. Similarly, Sedgwick struggles to come to terms with her equally treacherous fat cells, although these also wrap her in a warm sense of comfort and security. In Dialogues of Love she writes that her breast cancer helped her experience her body as a body, but only once some parts were gone: 'I had the two breasts / I kept forgetting them. They / weren't there for me' (p.78) and in Fat Art, Thin Art she describes how she discovered the inherent virtue of fat when she missed the warmth of her husband's embrace. Tendencies states that her female body became real to her once part of it was removed. Like Helen Memel, Sedgwick explores the unchartered territories of her corporeal self and she finds a new fleshy fluidity that the conventional boundaries of embodied experience cannot account for.

Also like Helen, Sedgwick only recognises her body's fluidity when its normalised and expected functions fail her - and her experiences of corporeal being thus become negotiated in terms of abjection, otherisation, illness and disease. As Sedgwick attempts to re-internalise her transforming physical form, her horizons widen. She describes how the struggle against cancer curiously expands her identity and sense of self in time with the cancer cells' expansion of her tissues. The cancerous experiences become her self and her rhizomatic cell growths inflate the scope of her mind to develop a poetics of membranous multi-sensorial experience.

Sedgwick's becoming-cancer and becoming-fat is not dissimilar to Helen Memel's becoming-slime. Both Sedgwick and Roche attempt to formulate a new corporealised 'Dasein' or sense of self. Roche shows that the awareness and contemplation of bodily mucous and mucous substances is necessary for an awareness of a body, the workings of which are often taken for granted, and Sedgwick demonstrates how this awareness mounts in the moments when they fail. The truth that emerges is that physical fluidity cannot be separated from the scope of embodied experience, however much we abjectify it. Our membranous wetlands constantly remind us that the corporeal determines being and being is slime.

\section{Part 2: Becoming-Fluid}

What does this mean for our project of refluidifying corporeality? What can these texts do for our cultural conception of the body? Although Bob Flanagan, Helen Memel and Eve Kosofsky Sedgwick give new life to the sliminess of embodiment, their experiences lead to fleeting moments of 
discursive change or boundless, porous fluidity. Their texts ontologise, and the ontological always already remains bound to the individual, a spatio-temporally determined subject, a being in time. Any attempt to transcend these perimeters would doubtless prove hubristic, but as Aristotle's Poetics remind us, hubris (and eventual failure) is a necessary component of the truly cathartic textual exploit. In the spirit of this ancient wisdom, the corporeal bounds of our introduction will now dissolve and its alluvial, temporal, subjective and logical flows will decentre and disperse. Each of its fluids will run in its own separate direction, but in their scattered courses they will reconvene, commune and correspond.

\section{Blood}

[W]e are now ariued in these meadowes, where the vessels like so many brookes do water and refresh this pleasant Paradise or model of heauen and earth; I mean the body of man. And surely by these streames doe grow many pleasant flowers of learning to entertaine and delight our minds beside the maine profit arising there from unto the perfection of that Art we have in hand. (Crooke, 1631, p. 825)

As the English physician Helkiah Crooke puts it in his Mikrokosmographia (1615), our blood vessels are like rivers, from which "doe flow into all the parts of the body Blood, Heate, Spirit, Life, Motion and Sense" (p. 825). All these concepts are curiously synonymous in Crooke's corporeal philosophy - and through them, the lifeless flesh blossoms with vitality and sensibility.

Crooke bases a large amount of his theories on ancient sources like Galen and Aristotle, although his views of the various physical processes also contradict some of their basic tenets. He develops Aristotelian notions of vitality and the 'soul' as a division between three different spirits into a theory of three types of blood: "Nature therefore because the Spirites are of three sorts, Naturall, Vitall, and Animall, hath prepared three kindes of Vesselles for their transportation, Veines, Arteries and Sinews" (Crooke, 1631, p. 824). Physiological 'perfection' is a balance of these three vessels, and their spiritual charge. The arteries carry the hotter, more unruly and impure spirits, and they catch the various nasty vapours and waste products of the body on their way through the various organs and muscles. The veins transport the purer vital spirit to its various parts - and the purest and hottest animal spirit is delivered to the brain through the nerves or sinews (p. 824). 
Through its continual motion, the heart is the dispenser of all three spirits, although they are destined for different vessels. The left ventricle heats, spreads and nourishes the spirits - and in quick and nimble motions feeds the veins (Crooke, 1631, p. 128). However, as Crooke establishes, the heart also has the power to transform the blood and the spirits - the right ventricle cools and slows the arterial blood down, expunging "smoky and fumed vapours", causing anger and malcontent, and ensuring the spirits are not clouded by unsavoury substances (p. 824). A balanced heart, with a balanced amount and quality of blood running through it, could take care of external as well as internally produced dangers.

Although Crooke wrote before William Harvey's discovery of the circulation of the blood (in 1628), his conception of vitality and corporeality relies on continual circularity, fluctuation and porousness - a quality considered most clearly pronounced in women (Delaney, p. 46). This is why William Shakespeare's Lady Macbeth implores "the spirits" that "tend on mortal thoughts" to "unsex" her she wants her heart made hard and impenetrable (1.5.39-40; p. 15). A hardened and unmoving heart would shrivel and clog up, obstructing the enspiriting and life-giving "brookes". Lady Macbeth wants it to "make thick my blood, / Stop up th'access and passage to remorse" (1.5.42-3; p. 15), and this would indeed make her murderous intent unshakable. The "fumed" arterial blood would never be purged, strengthening her malice, and her womanly compunctions would remain unstirred, as the vital and affective spirits would not reach their required outlets. A hardened heart is a spiritual closure and a vaporous build-up, not merely in the blood, but in the whole body, "by the veynes, the whole body hath a kind of connexion or coherence" (Crooke, 1631, p. 827). An obstructed heart would lead to melancholy, spiritual and mental decline, and ultimately madness.

Arterial bloodletting could relieve us momentarily - and in Macbeth, there is a continuous bloodletting of the body politic. As the heroic MacDuff and Malcolm point out at the play's violent conclusion, Scotland under Macbeth's rule bleeds and bleeds - as its tyrannous head, Macbeth, and its heart, his wife, try to purge her of all threats to their rule (4.3.30-108, p. 64-6). But "they say, blood will / have blood" (3.4.124-5, p. 49), and as the play progresses, it becomes clear that the toxic element distempering the country is the unnatural deed that became its ruler's inauguration, for as the doctor who tends the maddened Lady Macbeth declares, "Unnatural deeds / Do breed unnatural troubles" (5.1.70-1, p. 73). As Malcolm says, the only medicine for such a "deadly grief" is a "great revenge" (4.3.18-9, p. 70). If the initial murder of Duncan is presented as a stopping of the 
"great spring", "head", "fountain" or "source" of Scotland's blood (2.3.98-9, p. 31), the final decapitation of Macbeth is the cathartic purge that closes and heals her many gashes and wounds.

\section{Seed}

Macbeth and the doctor speak of blood having blood and unnatural deeds breeding unnatural troubles. Macbeth features numerous parenting metaphors, and the protagonist is greatly perturbed by the witches' revelation that Banquo's seed one day will take his place as king. Macbeth has no offspring of his own, and thus has no direct successor to the throne. The idea of his "fruitless crown" and "barren sceptre" is devastating to him (3.1.60-1, p. 37). Once informed of his future as Scotland's king, he spills the nation's blood like his fellow men would spill their seed. His generational offering is fear and violence, and fed by Lady Macbeth's mother's milk, which she has requested be taken "for gall" (1.5.47, p. 16), they parent a country built on destruction.

Like most contemporary physicians, Helkiah Crooke, as well as William Harvey, believed that seed, blood and mother's milk were composed of the same elements. Mother's milk is highly nourished blood from the womb, transported to the breast and "pulled and drawn" by the mammary glands into milk. Also seed, which both men and women possess, is continually produced from blood. The testicles, or "spermatic glands" boil and heat the blood to the extreme, charging it with spirit - and this concoction is eventually led to the "parts of generation" through the spermatic vessels to be mixed and moulded during coitus. The excited vessels and spirited blood of each parent is thus the innermost core of the created child. Indeed, as Harvey indicates, it is the initial little red spark of life we see pulsating in the minuscule shape of the newly formed foetus (p. 60).

Yet seed, like blood, may be corrupted - and as another of Shakespeare's great tragic protagonists experiences, so can its fruit. King Lear's great scourge is the "unnatural" (2.4.274, p. 93) actions and cruelty of his daughters Goneril and Regan (and Cordelia, although she in actuality shows him sincerity). There is a "disease" (1.1.165, p. 14) and "degeneracy" $(1.4 .231$, p. 48) in his seed that he cannot fathom - and he soon realises that the deformity of his daughters, stems from an infirmity in his own body: "twas this flesh begot those Pelican daughters" (3.4.69-70, p. 110). Lear's blood is clouded - and his flesh is distempered by Goneril and Regan's betrayal: "thou art my flesh, my blood, my daughter, / Or rather a disease that's in my flesh, / Which I must needs call mine, Thou 
art a boil, / A plague-sore, an embossèd carbuncle, / In my corrupted blood" (2.4.217-21, p. 90). And when his blood is boiled increasingly out of temper, his spirit and mind becomes increasingly infirm, for "nature, being oppressed, commands the mind / To suffer with the body" (2.4.102-3, p.84).

The "infirmity" (1.1.293, p. 22) of Lear's body responds to the "deformity" $(4.2 .36$, p. 136) of his seed - and as such, the very course of nature becomes a curse. He rails at the whole concept of generation, asking the tempestuous spirits to "crack nature's moulds, all germens spill at once" (3.2.8, p. 99). Lear requests a dissolution of the "offices of nature, bond of childhood" $(2.4 .174, \mathrm{p}$. 88) - a purgation of his corrupted seed and a liberation of his confined spirit. As it turns out, this can only be accomplished through the eradication of his diseased bloodline.

\section{Milk}

Squeeze! squeeze! squeeze! all the morning long; I squeezed that sperm till I myself almost melted into it; I squeezed that sperm till a strange sort of insanity came over me; and I found myself unwittingly squeezing my co-laborers' hands in it, mistaking their hands for the gentle globules. ... Come; let us squeeze hands all round; nay, let us all squeeze ourselves into each other; let us squeeze ourselves universally into the very milk and sperm of kindness. (Melville, 1922, p. 393)

Seemingly boundless contingency lies in this phrase, dripping with the gelatinous gore of a sperm whale's congealing fleshy insides, Ishmael's sailor arms liquefying into a protean slime, his clutching fingers roping together a perverse, stewing compassion of fluids. Squeezed, he melts into his object other. Squeezing, he finds himself oozing at the seams, blending into gelatinous clods, becoming wet, creamy, localised, mixed.

Milk is the sweet soup of fertility and leisure - of Biblical bliss (The Bible, King James Version, Exodus 3.8) and mythological survival. When Romulus and Remus, abandoned at the river Tiber, suckle lupine teats under the shade of a wild fig-tree (Plutarch, Langhorne and Langhorne, 1831, p. 14), they build a city on this milk. Meanwhile, the land of Israel runs rich with milk and honey. Yet how surprising that these biblical rivers bear a sour, fermented tang (DuPuis, 2002, p. 29): the milk of the wolf taints generations of Romans with an insatiable hunger for 'blood and tyranny, ... eager 
and hungry after riches' (Justin and Watson, 1853, [38.6]). From the nipple to the mouth and then into the blood, milk curdles; more, it itself ingests - it swallows whaleman Ishmael in its kindness and saturates the Latin twins in cruelty.

Milk, then, is a fluid of drowning and death (or in Crooke's case, the very opposite - excitation and life), yet still, regardless, the ambrosia of unlimited possibility. It is that monstrous white which Michel Serres identifies so aptly in Genesis as a blank, uniform field, a rising tide of erasure (p. 779). What Serres makes so startlingly evident - what realisation activates in Ishmael a sheer and immense "panic to the soul" (Melville, 1922, p. 179), despite his throes of spermy ecstasy - is that we do not necessarily pollute the clear expanse of milk with drops of foreign colour, but that, conversely, milk consumes the colour, bleaching it with a field of white. Perhaps, as Melville's whaler muses on the strange and forbidding shade, this indefinite unity of colourlessness, soiling as it cleanses and purifying what it dirties, thus "stabs us from behind with the thought of annihilation" (Melville, 1922, p. 186).

Massaged and enfolded in many sailors' hands, Ishmael marvels as his borders begin to disintegrate: "my fingers felt like eels, and began, as it were, to serpentine and spiralise" (p. 392). As he squeezes unctuous lumps of whale jelly, he begins to squeeze himself, blend himself, milk himself into this mysterious, fleshy pool of fluid solidarity - becoming white. And what is white but "the visible absence of colour, and at the same time the concrete of all colours", a violently terrifying and seductive, senseless mixture of "dumb blankness, full of meaning"? (p. 186) It is in this blanched-white milk and sperm that Ishmael finds himself corrupted - indeed, himself infecting - with ineffable, unrelenting and universal kindness.

\section{Pus}

Left to warm and incubate, of course, milk separates. It spoils. Beyond the creamy, bottomless depths of oblivion - implicated, perhaps, in the fear of the mother, the dread of the teat, the terror of the breast - we find another obvious contaminate, that of time. Ravaged by bacteria, milk curdles, reeks and congeals like Melville's sweet spermaceti into strange, rancid, amorphous masses. We are talking now of the milk of corruption and disease. Time turns the liquids of the body into pus. 
Roman medical encyclopaedist Aulus Cornelius Celsus writes in De Medicina, "Ubi pus, ibi evacua" - where there is pus, there evacuate it. The purulent body is not a healthy body, Celsus's adage infers. We must cast pus out of the body proper, turn away both materially from the abject and existentially from the abyssal possibility of irredeemably fluid Being (and this is of course what King Lear tries to do to Regan, the 'carbuncle' of his 'corrupted blood').

Before an awareness of bacterial infection and a theory of germs, discoloured and odorous pus was a fluid emanation of the miasmic essence of disease. Consider for a moment what we now understand to constitute pus: born from infection, it is produced from the amalgam signs of bacterial contamination, of our own living matter and of our dead cells. This is an oxymoronical living decay: pus is literally and metaphorically the rotten disease of flesh (not upon flesh), whereby the very matter constituting our body gives itself to death (see Peyroux, 2000, p. 177). Pus, then, is a tauntingly ambiguous substance, unrelentingly borderline. The presence of this viscous mucous reminds us, terrifyingly and revoltingly, of how our sentient and presumably healthy bodies are constantly undermined by the powerless state of failure, rot and crisis.

This is the boundary that Kristeva writes of, "the border of my condition as a living being" from which the body as alive extricates itself (p. 3). This is where we turn away from such miasmic confrontations, doing a Heideggerian pirouette which promises to secure our beings as individual, autonomous and whole. But the border, Kristeva indicates, is always terrifyingly uncertain - or rather, terrifying because it is uncertain, because it requires constant redefinition to keep it other to our selves. In anxiety, we recall that the ailing body forever haunts the substance of its clean and pure counterpart; just so, the smell of decay indistinguishably haunts the lush, nurturing possibilities of milk. With a mere drop of vinegar, we sour from Ishmael's white milk of kindness to the milky white of decay, and from clear unanimity to the repugnant abjection that it carries in potentia. Imminent and immanent, we turn away from this corporeal contamination again, now again, indefinitely.

Cancerous Andrea, with breasts putrefying from a cancerous affliction, emanates such a noxious odour from her suppurating sores that St Catherine of Siena (1347-1380), stalwart companion of diseased pariahs, nearly vomits (Raymond of Capua, 1860, p. 102; Morrison, 2003, p. 210-211). But in an ascetic gesture of absolute devotion of her body to God, she swallows down her disgust, 
presses her lips down upon the pussy mammary and drinks rotten milk from the teat of her patient's wound.

St Catherine gags, almost throws up in the presence of this milky putrescence, not because of what it contains, but because of what it is - an ulcer of living decay. As punishment for her stomach's impious revulsion, the saint suckles the breast even as it seeps foul discharge (Raymond of Capua, 1860 , p. 102); ingesting pus, she wishes herself redeemed for rejecting the malodorous spectre of death. Yet, paradoxically, by consuming the pustular, she nonetheless casts away this shadow of decay and triumphs over death (p. 102); indeed, she brings herself closer to something greater than life, something divine (p. 106).

This rejected corporeal sap opens lines of communication between the abject-other and God, leading into infinite jouissance (Kristeva, 1982, p. 126-7). It is a move of sheer transcendence which plunges Being into the purulent detritus of the body proper and, by sinking below the threshold of the whole into the anguish of confronting incompleteness, compels Being itself to turn away from the corruption and find an divine awareness of something higher than itself - transcendental Being.

Bataille writes in Inner Experience, "[i]n ascesis, value is not that of experience alone, independent of pleasure or of suffering; it is always a beatitude, a deliverance, which we strive to procure" (p. 22). Pus is thus once again rejected rather than accepted, rendered significant only as the otherised vehicle which may carry one towards the knowledge of God. Gone is Ishmael's milk of fluid congeniality: instead, taking in this infected juice immediately instrumentalises it, bringing St Catherine beyond it, transcendent rather than present, separated rather than mixed.

Leprous Andrea dies, repentant abject object, her sour milk on Catherine's pious, saintly tongue.

\section{Saliva}

In the mouth, fluids mingle; the hole of the outside-becoming-inside is rarely kept shut from the two-way passage of substances. In the mouth, pus and milk both turn to spit, where only the lingering hint of taste remains. As late as the sixteenth century, saliva was characterised as an excrement or filter of the blood, a by-product of straining or cleansing through the brain (Garrett, 1975 , p. 553). Only three centuries later was the theory of saliva as the dirty dregs of bodily 
filtration finally debunked entirely and biologists begin to recognise this fluid as a selective gatekeeper, incorporating some substances and rejecting others (Garrett, 1975 p. 555-6).

Yet spit still harbours the twin hats of castaway and custodian; it is undeniably vested with a pervasive and persistent ambivalence. The exchange of fluids through the passage of the mouth, of milk and pus into saliva, is both an unmaking and a claiming: it is a surrender and an invasion. Yet beyond, between and within this pitted and formal antagonism of effects - the self-expunging ecstasy of squeezing Ishmael and the rupturing discipline of St Catherine's objectivising suckle there is also a kind of an ever-renegotiating sharing.

What silently traverses the lips, carried in the stream of texture and taste, is an intimacy that refuses form and signification; that, as Luce Irigaray suggests, fluctuates, blurs and overflows the subject ( $p$. 112), that quietly defies the mechanics of solids. Inside the mouth, Jean-Luc Nancy explores this communality as "joying", "not appeasement, but a serenity without rest. To joy is not to be satisfied - it is to be filled, overflowed. It is to be cut across" (p. 106). He continues:

The joy of joying does not come back to anyone, neither to me or to you, for in each it opens the other. In the one and the other, and in the one by the other, joy offers being itself, it makes being felt, shared. ... to joy is an extremity of presence, self exposed, presence of self joying outside itself, in a presence that no present absorbs and that does not (re)present, but that offers itself endlessly (p. 107).

The salivary, we must admit here, analogises a continually shifting economy of fluids which delivers up what Nancy defines as "singular being" (p. 27-8). Being appears only ever with another between blood and seed, mouth and milk, lips and pus - in the sharing of finitudes and singularities (Nancy, 1991, p. 28), or elsewhere defined as the friction between two infinitely neighbouring entities, "quasi contact between two unities hardly definable as such" (Irigaray, 1985, p. 111). Being, then, is forever multiply singular, dependent in fits and flows, "continuous, compressible, dilatable, viscous, conductible, diffusable, ..." (p. 111).

The flow of bodily fluids brings about us, momentarily dense and discernible at our liquid limits. To cede this dynamics of fluids to a rationality of corporeal solidity thus not only threatens the self but 
performs its very execution. This text thus ceaselessly shifts and stirs its attention, gathered and accumulated from the material - from blood, seed, milk, pus and spit - to envelope the ontological. Yet again, this suggests nothing more than that both the material and the ontological are the alluvial mess of a contagious corporeality: of milk, pus, saliva, fat, piss, faeces, vomit, sweat, tears, sperm, cum, snot, mucus, and a host of so many other bodily fluids, that bring being into full, embodied focus.

Between us, 'hardness' isn't necessary. We know the contours of our bodies well enough to love fluidity. Our density can do without trenchancy or rigidity. We are not drawn to dead bodies.

(Irigaray, 1985, p. 215)

\section{Notes}

${ }^{1}$ See e.g. The History of Sexuality, Vol. 1; 'Nietzsche, Genealogy, History' and Speech Begins after Death.

\section{Bibliography}

Bergson, H., 1998. Creative Evolution. Trans. A. Mitchell. New York: Dover Publications.

The Bible. Authorized King James Version with Apocrypha. 1998. Oxford: Oxford University Press.

Braidotti, R., 2002. Metamorphoses: Towards a Materialist Theory of Becoming. Cambridge: Polity Press, Print.

Cerbone, D. R., 2000. "Heidegger and Dasein's 'Bodily Nature': What is the Hidden Problematic?" International Journal of Philosophical Studies, 8.2, pp.209-230.

Crooke, H., 1631. Mikrokosmographia : a description of the body of man; together with the controversies and figures thereto belonging. 2nd Ed. London: Th. Cotes \& R. Young.

Delaney, J., 1988. The Curse: A Cultural History of Menstruation. Chicago: University of Illinois Press.

Deleuze, G. and Guattari, F., 2007. A Thousand Plateaus. Trans. Brian Massumi. London: Continuum.

DuPuis, E. M., 2002. Nature's Perfect Food: How Milk Became America's Drink. New York: New York University Press.

Flanagan, B., 1993. Bob Flanagan: Supermasochist. Research People Series: Vol. 1. Ed. A. Juno and V. Vale. San Francisco: Research Publications. 
Foucault, M., 1977. 'Nietzsche, Genealogy, History', Language, Counter-Memory, Practice: Selected Essays and Interviews by Michel Foucault Ed. D. F. Bouchard and S. Simon. Trans. D. F. Bouchard. Ithaca: Cornell.

---, 1990. The History of Sexuality, Volume 1: An Introduction. Trans. R. Hurley. London: Penguin.

---, 2011. Speech Begins after Death: In Conversation with Claude Bonnefoy. Ed. P. Artières. Trans. R. Bononno. Minneapolis: University of Minnesota Press.

Garrett, J. R., 1975. 'Changing Attitudes on Salivary Secretion - A Short History on Spit.' Proceedings of the Royal Society of Medicine, 68 (September): pp. 553-60.

Harvey, W., 1857. The Works of William Harvey, M.D. Physician to the King, Professor of Anatomy and Surgery to the College of Physicians. Trans. R. Willis. London: Sydenham Society.

Heidegger, M., 1993. Basic Writings: From Being and Time (1927) to The Task of Thinking (1964). Trans. D. F. Krell. Oxon: Routledge.

Heidegger, M., 2008. Being and Time. Trans. J. Macquarie and E. Robinson. London: HarperPerenial. Irigaray, L., 1985. This Sex which Is Not One. Trans. C. Porter and C. Burke. Ithaca: Cornell University Press.

Justinus, M. J. and Watson, J. S., 1853. Epitome of the Philippic History of Pompeius Trogus. Trans. John Selby Watson. London: Henry G. Bohn.

Kristeva, J., 1982. Powers of Horror. Trans. L. S. Roudiez. New York: Columbia University Press.

Nancy, J-L., 1991. The Inoperative Community. Theory and History of Literature series, vol. 76. Ed. P. Connor. Trans. P. Connor, L. Garbus, M. Holland and S. Sawhney. Minneapolis: University of Minnesota Press.

Martini, F. H. and Nath, J. L., 2009. Fundamentals of Anatomy \& Physiology. 8th ed. San Francisco: Pearson Benjamin Cummings.

Melville, H., 1922. Moby Dick; or, The White Whale. Boston: The St. Botolph Society.

Morrison, M., 2003. 'Ingesting Bodily Filth: Defilement in the Spirituality of Angela of Foligno'. Romance Quarterly, 50.3: pp. 204-216.

Peyroux, C., 2000. 'The Leper's Kiss'. In Monks \& Nuns, Saints \& Outcasts: Religion in Medieval Society. Ed. Barbara H. Rosenwein. Ithaca: Cornell University Press.

Plutarch, Langhorne, J. and Langhorne, W., 1831. Plutarch's Lives, Translated from the Original Greek: with Notes, Critical and Historical: And a Life of Plutarch. Trans. J. Langhorne and W. Langhorne. Baltimore: William and Joseph Neal.

Raymond of Capua, 1860. Life of St Catharine of Sienna. By the Blessed Raymond of Capua, Her Confessor. With an Appendix: Containing the Testimonies of Her Disciples, Recollections in Italy, and Her Iconography. Trans. E. Cartier and the Ladies of the Sacred Heart. Philadelphia: Peter F. Cunningham. 
Roche, C., 2010. Wetlands. Trans. T. Mohr. London: Grove Press.

Serres, M., 1997. Genesis. Studies in Literature and Science series. Trans. G. James and J. Nielson. Ann Arbor: University of Michigan Press.

Sedgwick, E. K., 1993. Tendencies. Durham: Duke University Press.

---, 2003. Touching Feeling: Affect, Pedagogy, Performativity. Durham: Duke University Press.

Sick: the Life and Death of Bob Flanagan, 1993 [Film] Directed by Kirby Dick. U.S.A.: Kirby Dick.

Shildrick, M., 1997. Leaky Bodies and Boundaries: Feminism, Postmodernism and (Bio)ethics. London: Routledge.

Shakespeare, W., 2007. King Lear. The Annotated Shakespeare. Ed. B. Raffel. New Haven: Yale University Press.

---, 1992. Macbeth. Ed. A. Quiller-Couch \& J. Dover Wilson. Ware: Wordsworth Classics.

Sjöholm, C., 2005. Kristeva and the Political. Abingdon: Routledge. 